\title{
Structural model of sandalwood (Santalum album) regeneration in the forest and community plantation in Timor Island, Indonesia
}

\author{
YOSEPH NAHAK SERAN ${ }^{1,3, »}$, SUDARTO $^{2}$, LUCHMAN HAKIM ${ }^{3}$, ENDANG ARISOESILANINGSIH $^{3}$ \\ ${ }^{1}$ Program of Biological Education, Faculty of Education and Teacher Training, Universitas Timor. JL. Jenderal Sudirman, Kefamenanu, \\ Timor Tengah Utara 85613, East Nusa Tenggara, Indonesia. Tel.: +62-388-31865, ^email: joshseran@ gmail.com \\ ${ }^{2}$ Department of Soil Science, Faculty of Agriculture-Universitas Brawijaya, Malang, East Java, Indonesia \\ ${ }^{3}$ Department of Biology, Faculty of Mathematics and Natural Sciences, Universitas Brawijaya. J1. Veteran, Malang 65145, East Java, Indonesia
}

Manuscript received: 20 October 2018. Revision accepted: 20 November 2018.

\begin{abstract}
Seran YN, Sudarto, Hakim L, Arisoesilaningsih E. 2018. Structural model of sandalwood (Santalum album) regeneration in the forest and community plantation in Timor Island, Indonesia. Trop Drylands 2: 41-47. Sandalwood (Santalum album L.) is a very important forest product in Nusa Tenggara Timur (NTT) Province, Indonesia due to its high economic value. However, the population of sandalwood is threatened, requiring regeneration to enhance its population. This study aimed to identify and produce a structural model of sandalwood regeneration in both natural forest and the community plantation in the districts of Timor Tengah Selatan (TTS) and Timor Tengah Utara (TTU), NTT Province. The method used in this research was vegetation analysis using purposive sampling method at 8 observation stations with total of 87 plots. The plot size was $20 \times 20 \mathrm{~m}^{2}$ (trees), $10 \times 10 \mathrm{~m}^{2}$ (poles), $5 \times 5 \mathrm{~m}^{2}$ (saplings), and $2 \times 2$ $\mathrm{m}^{2}$ (seedlings). Data observed in the field included the mean sandalwood population size in the forms of trees, poles, saplings and seedlings phase; vegetation data in sandalwood habitat which included tree wealth index, diversity index, number of individuals and sandalwood host diversity index data. Geographical factors such as altitude and slope, and abiotic factors such as soil organic matter, soil $\mathrm{pH}$ and soil conductivity were also recorded. Climate data included the number of dry months and rainfall. Sandalwood regeneration data included sandalwood vitality, pests and diseases, and the number of seeds. Secondary data included climate data (ten years time) obtained from BMKG. Altogether, these data were used as the indicators of the latent variables (six variables) which consisted of geography, soil, climate, population, vegetation, and regeneration. Obtained data were subjected to both descriptive analysis and multivariate statistics with structural modeling of Warp Partial Least Square (WarpPLS 6.0). The results showed that most of the proposed indicators significantly influenced the six latent variables except the host diversity. Some indicators significantly or highly significantly affected the latent variable with 15 indicators that significantly composed the latent variable. The resulting structural model had of Q2 predictive value of 96,65\%, suggesting that the structural model proposed in this study has very relevant and high prediction on factors that influence sandalwood regeneration. Therefore, this model is feasible to be used as recommendations in the framework of sandalwood development in the forest and the community plantation in the West part of Timor Island, Nusa Tenggara Timur.
\end{abstract}

Keywords: Forests, plantations, regeneration, sandalwood, Santalum album, structural models

Abbreviations: NTT: Nusa Tenggara Timur, TTS: Timor Tengah Selatan, TTU: Timor Tengah Utara, Warp PLS: Warp Partial Least Square

\section{INTRODUCTION}

Sandalwood (Santalum album L.) is one of the most important forest products in Nusa Tenggara Timur (NTT) Province because it has high economic value. Yet, it has great conservation importance since it is an endemic species and is currently threatened with extinction (IUCN 2016). Therefore, the conservation and sustainable utilization of this species are essential for its long-term existence. One of important strategies for the conservation of sandalwood is by improving their population through regeneration.

Regeneration is vital because the current population of sandalwood in forests and gardens/plantations is very limited. The success of regeneration in forest is highly dependent on seed production and dispersal, seed germination into seedling, and seedling growth into juvenile (e.g. saplings) and adult stage (e.g. mature trees) (Wijayanto et al. 2011). The natural regeneration process is also influenced by the vitality (degree of success or life cycle) of a species in the habitat. Vitality determines the survival and growth rate of a species in response to environmental changes. In studying vitality, there are several indicators that can be used to determine whether the life cycle of a species is complete or not (Braun-Blanquet 1932; Doberrtin 2005). Vitality of 1 (one) means that the species can develop life cycle well and entirely through the stages of seedling, sapling, poles, and trees. Vitality of 2 means that the species can develop life cycle relatively well but is irregular. Vitality of 3 means that the species experiences a rare and incomplete life cycle in its habitat. Vitality of 4 means that the species have incomplete life cycle with only few seedlings and very few are able to survive

Natural regeneration of sandalwood in forest through seeds or root shoots are lacking due to habitat degradation and limited parental trees/seed sources. Thus, sandalwood regeneration depends largely on the success of sandalwood 
cultivation carried out by local communities in agroforestry systems using secondary host plants (Wawo 2008). Sandalwood agroforestry systems applied in the community gardens/plantation can restore the sandalwood populations. The distribution and population density of sandalwood in agroforestry showed promising pre-liminary outcomes (Wiharto et al. 2008). However, sandalwood planting activities carried out in NTT are still very low with only 429 ha per year planted over a five years period (2004-2008). The efforts of sandalwood cultivation implemented by the government or related institutions through the Forestry Office are still very low, with only less than $30 \%$ of total sandalwood planting (Darmokusumo 2001; Surata 2006). In contrast, sandalwood logging activities reached 6.200-12.400 trees per year (Surata 2006).

One of the causes of the low success of sandalwood cultivation is pest and pathogens attacks, for example, the spike disease caused by mycoplasma which resulted in stunting and yellowing. Another pathogen that attacks sandalwood is reetdauw (sooty mold) with symptoms and signs of specks of mushrooms growing on the leaves. Some insects that attach sandalwood include Zeuzeura ceffea (a type of butterfly that hoists the young branch of sandalwood), Chiaonapsis sp, Valanga nigricornis zehntneri Kraus, and snout beetle (Shobha 1990).

Based on the above-mentioned rationale, this study aimed to develop a structural model of sandalwood regeneration in natural forest and community plantation in Nusa Tenggara Timur Province, Indonesia.

\section{MATERIALS AND METHODS}

\section{Study area and period}

This research was conducted in the districts of Timor Tengah Selatan (TTS) and Timor Tengah Utara (TTU), Nusa Tenggara Timur Province, Indonesia (Figure 1) at eight observation stations consisting of 87 nested plots (Figure 2). Of the eight observation stations, five were located in TTS District (three stations in plantation and two stations in forest) and three were located in TTU District (one station in plantation and two stations in forest). Five stations in TTS District were Oelbubuk (Oe), Binaus (Bi), Nununamat $(\mathrm{Nu})$, Karang Siri $(\mathrm{Ks})$, Tetaf (Te). Three stations in TTU District were Upfaon (Up), Banamlaat (Ba), and Oinbit (Oi) (Figure 1). This research was conducted from September 2015 to December 2016.

\section{Data collection}

Field collected data included mean sandalwood population size in the form of trees, poles, saplings, seedlings phases, and vegetation data including tree wealth index, diversity index, number of individuals and sandalwood host diversity index. Geographical data included altitude and slope, soil organic matter, soil $\mathrm{pH}$ and soil conductivity, and the number of dry months and rainfall. Data regarding sandalwood regeneration included sandalwood vitality, pests and diseases, and number of seeds. These data were then used as indicators of the latent variables consisting of six namely geographical, soil, climate, population, vegetation and regeneration, while secondary data were in the form of climate data obtained from BMKG of NTT Province in Kupang (climate data for the last ten years at eight observation stations).
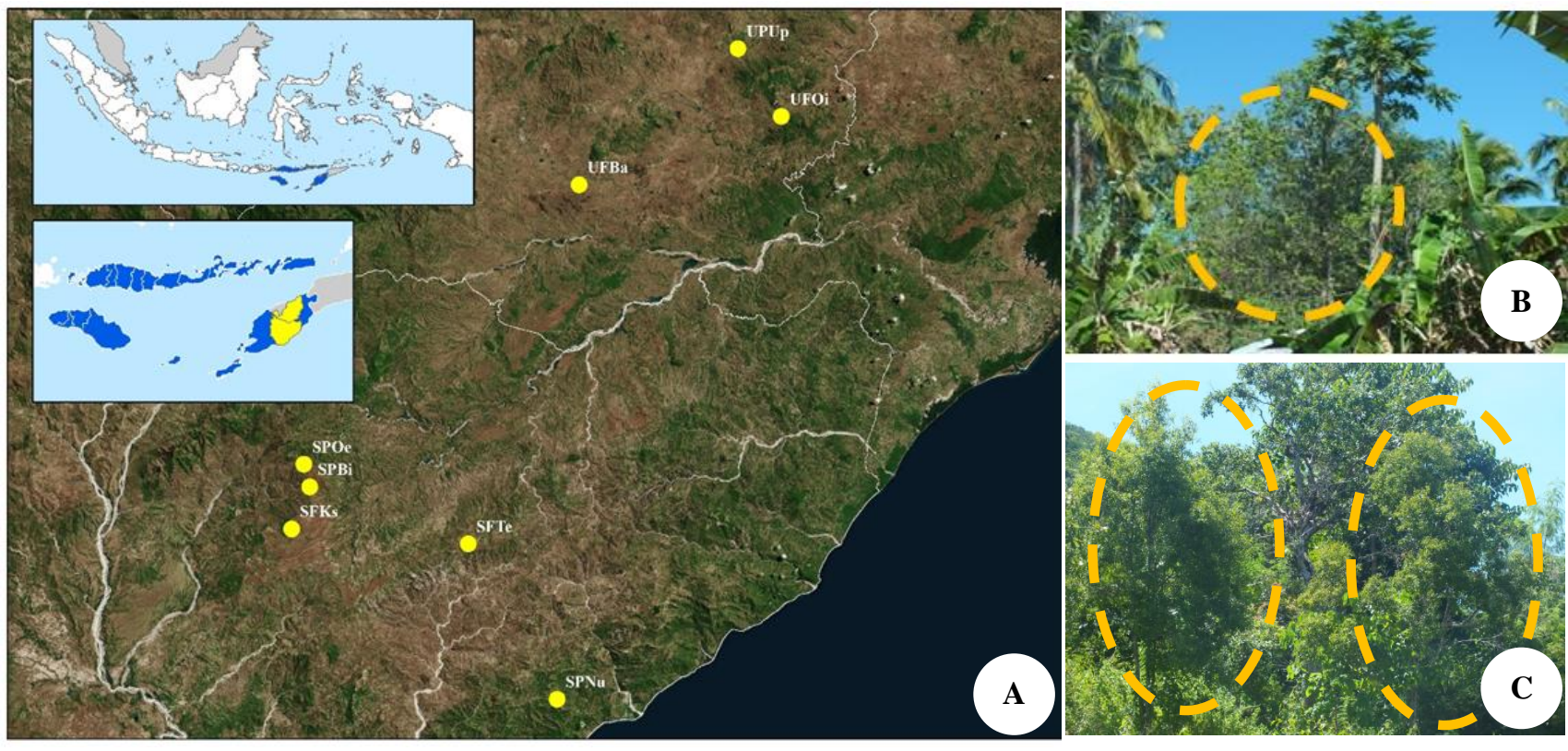

Figure 1. A. Map of the study area in the forest and community plantation in Timor Island, Indonesia, B. Sandalwood in mixedplantation, C. Sandalwood in forest. Note: SPNu: Soe Plantation Nununamat, UFOi: Kefa Forest Oinbit, UPUp: Kefa Plantation Upfaon, SFTe: Soe Forest Tetaf, SPOe: Soe Plantation Oelbubuk, SPBi: Soe Plantation Binaus, UFBa: Kefa Forest Banamlaat, SFKs: Soe Forest Karang Siri stations. Dashed lines indicate of sandalwood plant 


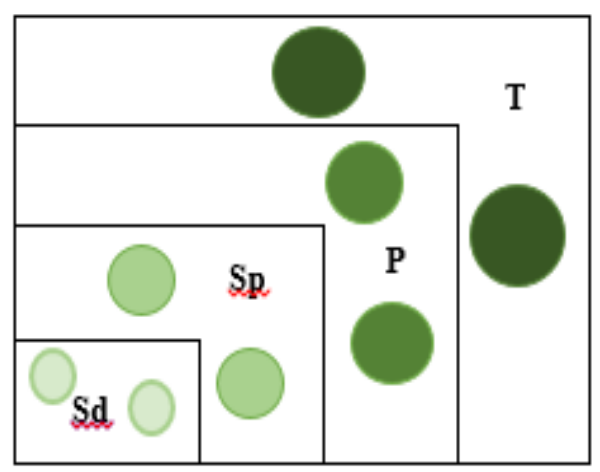

Figure 2. Nested plots. Note: T: Trees: 20 x $20 \mathrm{~m}$ plot, P: Poles: 10 x 10 m plot, Sp: Saplings: 5 x 5 m plot, Sd: Seedlings: 2 x 2 m plot.

\section{Data analysis}

Identification of limiting factors for sandalwood regeneration was analyzed using statistical methods of multivariate structural modeling with Warp Partial Least Square (WarpPLS 6.0). The interaction of limiting factors in sandalwood regeneration was determined using structural modeling with WarpPLS 6.0, following these steps. First (i), determining the latent variables with indicators of each variable consisting of 6 latent variables and 15 indicators. Second (ii), determining the design of a structural model, which describes the relationship between latent variables. Geographic variables become exogenous variables that influence the endogenous variables of vegetation, population size, and sandalwood regeneration. Soil variables become endogenous variables that affect vegetation, population size, and regeneration. Climate variables become endogenous variables that affect vegetation, population size, and regeneration. Vegetation variables become endogenous variables that affect population size and regeneration. Variable of population size become an endogenous variable that affects sandalwood regeneration. The relationship/correlation between variables from this research is unidirectional/ parallel so that the nature of the relationship is recursive. Third (iii), determining the design of the measurement model which describes the relationship between indicators with the intended latent variables. In this study, the direction of the relationship is from the indicator to the variable so that the nature of the indicator is formative. The relationship between latent variables and indicators compiled in this study are as follows: altitude and slope of the compiler of geographic variables; soil organic matter, $\mathrm{pH}$ and conductivity of soil variables compiler; rainfall and dry months, the constituent of climate variables; taxa wealth, species density, species diversity index, host diversity index of the vegetation variable compiler, population density of trees, poles, saplings, seedlings the constituent/compiler of sandalwood population size; vitality, number of seeds and disease the compiler of sandalwood regeneration variables. Fourth (iv), creating a path/line diagram construction of structural models, which describe the results of the determination of the measurement model design and structural model then arranged in the form of a structural model line diagram. The results of the structural model in line construction diagram are shown in Figure 3. Fifth (v), testing the measurement model and structural model, which describes the feasibility or not the indicator of the intended latent variables. The feasibility is determined by the t-statistics value. The indicator is said to be feasible as a constituent/ compiler of the latent variable if the t-statistic value is greater than 1.96. In the opposite condition if the indicator t-statistic value is less than 1.96, then the indicator is said to be inappropriate or insignificant as a compiler of latent variables so that the indicator is excluded from the structural model. Testing the structural model aims to determine the variables that relate significantly or directly to other variables, the direction of the relationship and the closeness of the relationship between variables. Variables correlate significantly if the t-statistic value is greater than 1.96. The direction of the relationship between variables is determined by the value of the coefficient of determination $\left(\mathrm{R}^{2}\right)$. Sixth (vi), testing the goodness of the structural model, which aims to determine the accuracy of the structural model built. The accuracy of the structural model is determined by the coefficient of determination $\left(\mathrm{R}^{2}\right)$ and predictive relevance $\left(\mathrm{Q}_{2}\right)$. Q2 value was calculated by the formula:

$$
\mathrm{Q} 2=1-\left(1-\mathrm{R} 1^{2}\right)\left(1-\mathrm{R} 2^{2}\right) \ldots \ldots\left(1-\mathrm{Rp}^{2}\right)
$$

where $\mathrm{R} 1^{2}, \mathrm{R} 2^{2}, \mathrm{Rp}^{2}$ are the determination coefficient $\left(\mathrm{R}^{2}\right)$ of the latent variable. Seventh (vi), hypothesis testing carried out by t-test on each path/line which has a partial direct effect. The analysis result is determined by looking at the probability or the value of t-statistic. The t-table value for alpha $5 \%$ is 1.96 so that the hypothesis acceptance criteria is when t-statistics $>\mathrm{t}$ table, namely $\mathrm{t}$ calculated $>1.96$. If the t-statistic value or $t$ calculated $>$ 1.96 then the path/line of the relationship between these variables is significant or has a direct influence (Guinot et al. 2001; Jaya and Sumertajaya 2008; Husein 2015).

\section{RESULTS AND DISCUSSION}

\section{Test results of the measurement model}

The study findings show that most of the proposed indicators were feasible or significant in compiling latent variables except the host diversity which had no significant influence on the latent variables (Table 1). The altitude, slope, and rainfall, as well as dry months indicators, had the same significant contribution to the combination of geographic and climate latent variables because they had the same measurement weights values namely 0.084 and 0.087. Soil organic material (BOT 10 and 20) gave an equal contribution to the formation of latent soil variables with a weighting value of 0.086 . Indicators of the individual number of saplings and seedlings had almost the same contribution in the composition of the sandalwood population latent variable because it had nearly the same measurement weight value namely 0.084 and 0.085 . The 
vitality, and pests and diseases, each contributed to the preparation of sandalwood regeneration latent variables with the weight of the measurement value of 0.090 and 0.093. Sandalwood host diversity, vitality, diseases, and pests, individual number of sandalwood trees and soil conductivity at a depth of $20 \mathrm{~cm}$ gave a highly significant influence on sandalwood regeneration. All indicators of each of the determined latent variables contributed significantly to the sandalwood regeneration process in both natural and cultivated habitats (Table 1).

The results showed that sandalwood can be isolated with other types of vegetation such as shrubs or grass without disturbing its growth. This is not too different from the results of the research by Surata et al. (2006) which stated sandalwood is a semi-tolerant plant that requires shade when it is 1-2 years old and when it is 3 years old sandalwood requires full sunlight and support from other environmental factors to survive. The studies by Putranto (2010) and Muskitta et al. (2017) stated that growth models and environmental conditions can be used to predict vegetation growth to formulate references for forest management.

\section{Results of test of goodness of fit of structural models}

Test of the goodness of fit of the model will provide information about how feasible the model is for sandalwood regeneration with the value of predictive relevance $\left(\mathrm{Q}^{2}\right)$ equals $96.65 \%$. Thus, the structured model has a very relevant and very accurate predictive value. The information contained in the data of $96.65 \%$ can be explained by the PLS model developed while $3.35 \%$ was described by other variables. The closeness of the relationship influence of one variable to another variable was determined by the value of determination $\left(\mathrm{R}^{2}\right)$. The climate $\mathrm{R}^{2}$ value was 0.493 , which means that the geographic latent variable effect on the climate is equal to $49.3 \%$. Geography and climate effect on the soil amounted to $38.2 \%$. Geography, climate and soil effects on vegetation were $50.6 \%$. The size of the sandalwood population was influenced by geography, climate, soil, and vegetation, i.e., 55.2\%. Sandalwood regeneration as an output model or response variable was influenced by geography, climate, soil, vegetation and sandalwood population by $38.2 \%$ (Table 2 ). The study results are also consistent with the research of Hadiyan et al. (2016) which shows that the vitality of sandalwood plants varies greatly between locations from various conservation plots caused by the environmental factors, varieties of sandalwood populations and genetic factors. The results of the study by Surata et al. (2001) showed that sandalwood can grow in dry climatic conditions of the D-E climate type, according to Schmidt and Ferguson's classification.

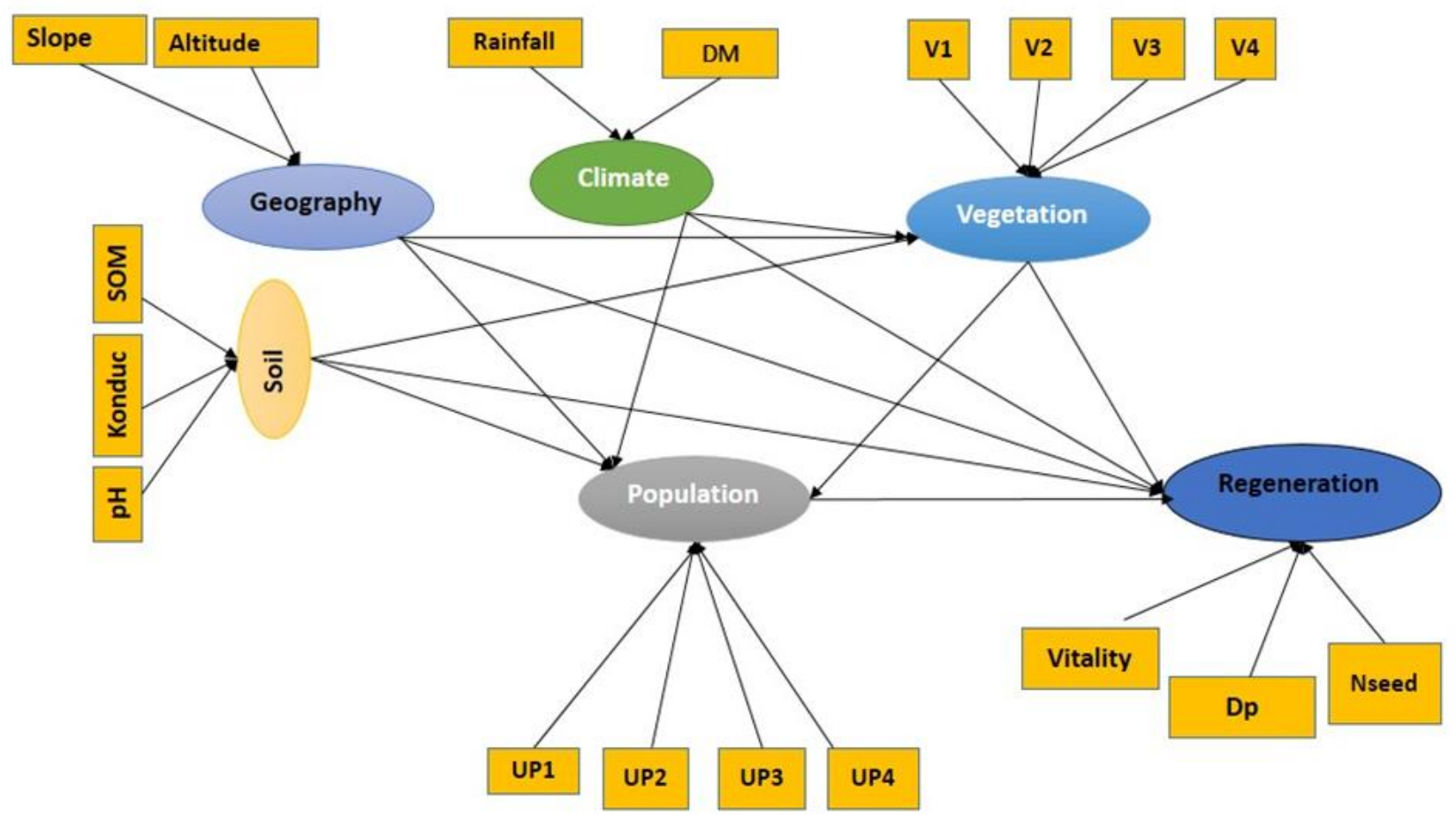

Figure 3. Model of the theoretical structure of exogenous latent variables that influence sandalwood regeneration in the forest and the community plantation in Timor Island. Figure Information: CH: Rainfall, BK: Dry month; V1: Vegetation density, V2: Taxa wealth, V3= Species diversity index, V4: Sandalwood host diversity index, SOM: Soil organic matter, Konduc: Soil conductivity; UP1: Trees population size, UP2: Size of the poles population, UP3: Saplings population size, UP4: Seedlings population size; Nbiji: Number of seeds, Vitality, Dp: Diseases and pets. 
Table 1. Indicators that are feasible/significant as the compiler of a latent variable on the testing results of the measurement model (combination of loading and cross-loading factor)

\begin{tabular}{|c|c|c|c|c|c|c|c|}
\hline $\begin{array}{l}\text { Variable/ } \\
\text { indicator }\end{array}$ & Geography & Climate & Vegetation & Soil & Population & Reg. & P-value \\
\hline Alt. & 0.851 & -0.349 & -0.029 & -0.540 & -0.023 & -0.037 & $<0.001$ \\
\hline Slope & 0.851 & 0.349 & 0.029 & 0.540 & 0.023 & 0.037 & $<0.001$ \\
\hline Rainfall & 0.248 & 0.702 & -0.056 & -0.480 & 0.045 & -0.085 & $<0.001$ \\
\hline Dry months & -0.248 & 0.702 & 0.056 & 0.480 & -0.045 & 0.085 & $<0.001$ \\
\hline $\mathrm{KP}_{-}(\operatorname{tax})$ & 0.132 & 0.235 & 0.830 & 0.267 & -0.009 & 0.023 & $<0.001$ \\
\hline $\mathrm{NP}_{-}$(ind) & -0.158 & -0.045 & 0.935 & -0.075 & -0.080 & -0.052 & $<0.001$ \\
\hline $\mathrm{H}^{\prime} \mathrm{P}$ & -0.040 & -0.298 & 0.789 & -0.283 & 0.110 & 0.024 & $<0.001$ \\
\hline Host & 0.828 & 0.970 & 0.084 & 0.850 & -0.054 & 0.128 & 0.212 \\
\hline BO10 & 0.088 & -0.048 & 0.164 & -0.745 & -0.143 & -0.063 & $<0.001$ \\
\hline BO20 & 0.038 & -0.062 & 0.186 & -0.745 & 0.018 & 0.010 & $<0.001$ \\
\hline $\mathrm{pH} 10$ & 0.038 & 0.088 & 0.143 & 0.834 & -0.040 & -0.077 & $<0.001$ \\
\hline $\mathrm{pH} 20$ & 0.146 & 0.102 & 0.124 & 0.743 & -0.088 & -0.048 & $<0.001$ \\
\hline Kond10 & 0.147 & -0.137 & -0.042 & 0.634 & 0.039 & 0.268 & $<0.001$ \\
\hline Kond 20 & -0.267 & -0.275 & 0.146 & 0.523 & -0.036 & -0.211 & $<0.001$ \\
\hline Trees & 0.030 & 0.342 & 0.196 & -0.321 & -0.550 & -0.480 & $<0.001$ \\
\hline Poles & -0.148 & 0.019 & 0.040 & -0.129 & 0.750 & -0.171 & $<0.001$ \\
\hline Saplings & 0.071 & 0.109 & 0.139 & 0.004 & 0.834 & 0.128 & $<0.001$ \\
\hline Seedlings & 0.086 & 0.104 & -0.047 & -0.104 & 0.803 & -0.303 & $<0.001$ \\
\hline Vitality & 0.123 & -0.665 & -0.159 & -0.140 & -0.305 & 0.587 & $<0.001$ \\
\hline Disease pets & 0.231 & 0.950 & 0.146 & 0.497 & -0.090 & 0.492 & $<0.001$ \\
\hline Number of seed & 0.249 & 0.104 & -0.029 & 0.218 & -0.299 & -0.747 & $<0.001$ \\
\hline
\end{tabular}

\section{Results of structural model testing of variable direct effect}

The result of structural model testing is to test the hypothesis. Hypothesis testing was conducted by t-test at $\mathrm{p}$ value $<0.05$ for significant and the $p$-value $<0.01$ for a highly significant effect on each path that had a direct or partial effect. The results indicated that the variables having an immediate effect were geographic, soil, and climate while the population had a direct impact on sandalwood regeneration. Meanwhile, vegetation had no significant effect on sandalwood regeneration. Vanclay (1994) states that the vegetation growth model is based on a system of statistical equations that can predict growth, regeneration, and yield of forest stands in various habitat conditions. However, to use this equation model, multivariate statistical tests need to be done with several variable combinations because each plant has different growth characteristics.

Table 2. Value of $\mathrm{R}^{2}$ and $1-\mathrm{R}^{2}$ for determination of $\mathrm{Q}^{2}$ value

\begin{tabular}{lcc}
\hline Endogenous latent variable & $\mathbf{R}^{\mathbf{2}}$ & $\mathbf{1 - R}^{\mathbf{2}}$ \\
\hline Climate & 0.493 & 0.507 \\
Soil & 0.506 & 0.452 \\
Vegetation & 0.548 & 0.494 \\
Population & 0.552 & 0.478 \\
Regeneration & 0.382 & 0.618 \\
\hline
\end{tabular}

\section{Results of structural model testing of indicator direct effect}

The result of structural model testing is to test the hypothesis. Hypothesis testing is conducted by looking at the p-value in each indicator and the path analysis coefficient value which shows a significant (direct) or partial relationship. The results showed that the indicator of the latent variable that did not give an immediate or significant effect was the sandalwood host, soil organic matter (BO10, 20, pH 10, 20, Kond 10, 20, tree population). Meanwhile, the other indicators had a direct or significant influence based on statistical tests with p-value $<0.001$ for sandalwood regeneration in natural habitats and cultivation (Table 3 ).

The insignificant relationship between these variables and indicators requires further testing in the next study, namely the linearity test to ensure that variables and indicators do not have a linear influence on other variables. The test results of the linearity test and the new structural model are arranged in the form of structural model path diagram shown in Figure 4. In this study, geographic variables had a direct effect on population and sandalwood regeneration but did not directly affect vegetation. Climate variables directly affected the population and sandalwood regeneration but did not directly affect vegetation. Soil variables directly affected vegetation and population but had no significant effect on sandalwood regeneration in natural and artificial habitats because sandalwood that grows in Timor Island can develop well in any type of soil. 
Table 3. The structural weight values of each latent variable and structural model test results indicators

\begin{tabular}{|c|c|c|c|c|}
\hline \multicolumn{2}{|c|}{ Variable/ indicator } & $\begin{array}{c}\text { Structural } \\
\text { weight }\end{array}$ & $\begin{array}{c}\mathbf{P} \\
\text { value }\end{array}$ & Information \\
\hline \multicolumn{5}{|l|}{ Geography } \\
\hline \multicolumn{2}{|l|}{ Alt. } & 0.500 & $<0.001$ & Significant \\
\hline \multicolumn{2}{|l|}{ Slope } & 0.500 & $<0.001$ & Significant \\
\hline \multicolumn{5}{|l|}{ Climate } \\
\hline \multicolumn{2}{|l|}{$\mathrm{CH}$} & 0.500 & $<0.001$ & Significant \\
\hline \multicolumn{2}{|l|}{ BK } & 0.500 & $<0.001$ & Significant \\
\hline \multicolumn{5}{|l|}{ Vegetation } \\
\hline \multicolumn{2}{|l|}{$\mathrm{KP}_{-}(\operatorname{tax})$} & 0.314 & $<0.001$ & Significant \\
\hline \multicolumn{2}{|l|}{$\mathrm{NP}_{-}$(ind) } & 0.399 & $<0.001$ & Significant \\
\hline \multicolumn{2}{|l|}{$\mathrm{H}^{\prime} \mathrm{P}$} & 0.284 & $<0.001$ & Significant \\
\hline \multicolumn{2}{|l|}{ Host } & 0.003 & 0.359 & Not Significant \\
\hline \multicolumn{5}{|l|}{ Soil } \\
\hline \multicolumn{2}{|l|}{$\mathrm{BO} 10$} & 0.183 & 0.008 & Significant \\
\hline \multicolumn{2}{|l|}{$\mathrm{BO} 20$} & 0.183 & 0.008 & Significant \\
\hline \multicolumn{2}{|l|}{ pH10 } & 0.229 & 0.003 & Significant \\
\hline \multicolumn{2}{|l|}{$\mathrm{pH} 20$} & 0.182 & 0.008 & Significant \\
\hline \multicolumn{2}{|l|}{ Kond10 } & 0.133 & 0.021 & Significant \\
\hline \multicolumn{2}{|l|}{ Kond 20} & 0.090 & 0.047 & Significant \\
\hline \multicolumn{5}{|c|}{ Population size } \\
\hline \multicolumn{5}{|c|}{ Tree $\quad 0.137$} \\
\hline Pole & 0.255 & & $<0.001$ & Significant \\
\hline Sapling & \multicolumn{2}{|l|}{0.316} & $<0.001$ & Significant \\
\hline Seedling & \multicolumn{2}{|l|}{0.292} & $<0.001$ & Significant \\
\hline \multicolumn{5}{|c|}{ Sandalwood regeneration } \\
\hline Vit. & \multicolumn{2}{|c|}{0.301} & $<0.001$ & Significant \\
\hline HP & \multicolumn{2}{|l|}{0.212} & $<0.001$ & Significant \\
\hline Nbiji & \multicolumn{2}{|l|}{0.487} & $<0.001$ & Significant \\
\hline
\end{tabular}

Vegetation variables had a direct effect on sandalwood populations but had no significant effect on sandalwood regeneration process, and population variables had a significant impact on sandalwood regeneration process, which means that the size of sandalwood tree, pole, sapling, and seedling population were very influential on sandalwood regeneration both naturally and in the community plantation. The test results of this structural model were also in line with the observational data at eight observation stations which showed that the number of sandalwood populations at all observation stations showed significant changes (sandalwood population increased) both in Timor Tengah Selatan (TTS) and Timor Tengah Utara (TTU) Districts. The research results showed that the model of sandalwood growth and regeneration varied greatly between locations. This is also in accordance with the observations of Haryjanto et al (2005), Zobel et al. (1984) and Hadiyan et al. (2017). The growth of sandalwood plants varies between observation plots caused by the differences in the factors of genetic, vegetation, geography, soil and climate.

In conclusion, the results showed that the relevance value of the prediction of Q2 was $96.65 \%$ indicating that the structural model proposed was highly relevant and had high predictive values for the factors that influenced sandalwood regeneration. Thus, this model is feasible or appropriate to be used as recommendations in the framework of sandalwood development in the forests and plantations in West Timor, Nusa Tenggara Timur Province, Indonesia.

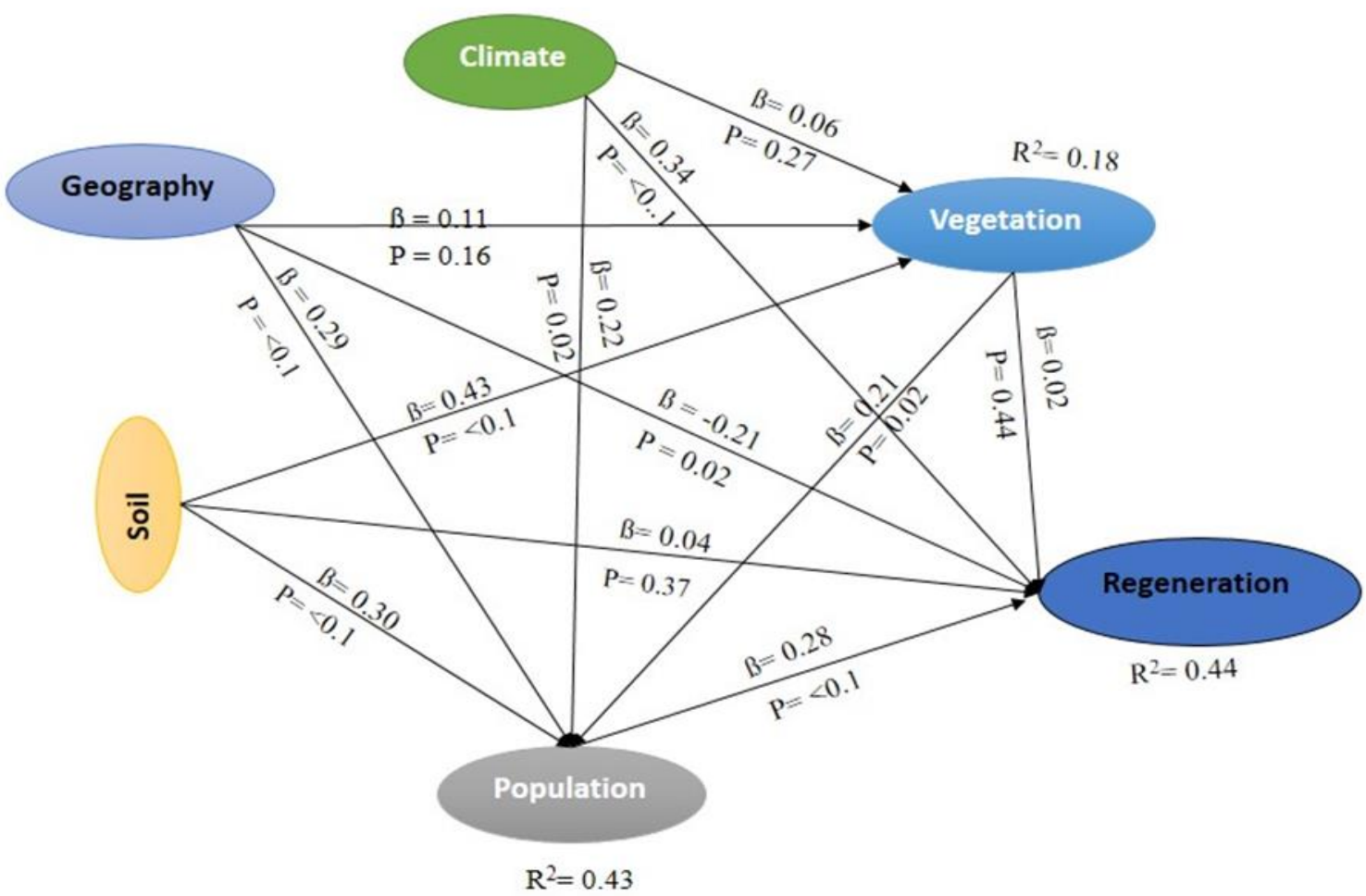

Figure 4. The structural model of the relationship/correlation of latent variables that affect sandalwood regeneration as a result of structural model testing which shows a significant relationship or had a direct effect with the $\mathrm{p}$-value $<0.05=$ significant, and $\mathrm{p}$-value $<$ $0.01=$ highly significant 


\section{ACKNOWLEDGEMENTS}

This research was funded by the Directorate General of Higher Education Indonesia-Research Fellowship (BPPDN). We are grateful to Muhamad Yusuf, Hamdani, Purnomo (Laboratory of Ecology and Animal Diversity, UB, Malang), Yossi (Laboratory of SIG, UB, Malang), as well as Firmo Seran Makbalin and Markus for their support in this research; and to all the students of Universitas Timor, Kefamenanu who assisted in collecting the field data.

\section{REFERENCES}

Braun-Blanquet J. 1932. Plant Sociology; the Study of Plant Communities. McGraw Hill, New York, USA.

Doberrtin M. 2005. Tree growth as indicator of tree vitality and of tree reaction to environmental stress: a review. Eur J For Res 124 (4) 319-333.

Darmokusumo S, Nugroho AA, Botu EU, Jehamat A, Benggu M. 2001. Upaya memperluas kawasan ekonomi cendana di NTT. Prosiding Cendana (Santalum album L.) Sumber Daya Otonomi Daerah Nusa Tenggara Timur. Berita Biologi Edisi Khusus 5 (5): 509-515. [Indonesian]

Hadiyan Y, Fiani A. 2016. Adaptability and Growth Performance of Sandalwood (Santalum album L.,) Ex-situ Conservation in Gunung Kidul District, Indonesian. Balai Besar Penelitian Bioteknologi dan Pemuliaan Tanaman Hutan, Yogyakarta. [Indonesian]

Hadiyan Y, Fiani A. 2017. Studi adaptasi dan kinerja pertumbuhan cendana (Santalum album L.) pada umur sebelas tahun di Watusipat, Gunung Kidul, Yogyakarta, Indonesian. J Solum 14 (2): 83-88. [Indonesian]

Haryjanto L, Pamungkas T. 2005. Variasi Pertumbuhan Cendana dari berbagai Prvenans pada umur delapan bulan. Jurnal Penelitian Hutan Tanaman 2 (2): 88-94. [Indonesian]

Guinot C, Latreille J, Tenenhaus M. 2001. PLS Path Modelling and Multiple Table Analysis. Application to the Cosmetic Habits of
Women in Ile-de-France. Chemometrics and Intelligent Laboratory Sistem.

IUCN. 2016. The IUCN Redlist of Threatened Species. Version 2016-2. www.iucnredlist.org.

Jaya IGNM, Sumertajaya IM. 2008. Pemodelan Persamaan Struktural dengan Partial Least Square. Seminar Nasional Matematika dan Pendidikan Matematika P: 118-132. [Indonesian]

Muller-Dombois D, Ellenberg H. 1974. Aims and Methods of Vegetation Ecology. John Willey and Sons, New York.

Muskitta E, Sanusi D, Putranto B. 2017. Growth Prediction Model of Cendana (Santalum album Linn.) at Private Land. Program Pascasarjana, Universitas Hasannudin, Makasar. [Indonesian]

Putranto B. 2010. Model Distribusi Diameter, Volume dan Pertumbuhan Lima Jenis Pohon pada Hutan Tropika Basah di Mamuju. [Disertasi]. Pascasarjana Universitas Hasannudin, Makasar. [Indonesian]

Solimun Adji RF, Nurjanah. 2017. Pemodelan Persamaan Struktural dengan Pendekatan WarpPLS. UB Press, Malang.

Surata IK, Idris MM. 2001. Status Penelitian Cendana di Provinsi Nusa Tenggara Timur. Edisi khusus masalah cendana NTT. Berita Biologi 5 (5): 521-537. [Indonesian]

Surata IK. 2006. Teknik Pengembangan Budidaya Cendana (Santalum album L.) di Lahan Masyarakat. Pusat Penelitian dan Pengembangan Hutan, Bogor. [Indonesian]

Shobha NR. 1990. Status and Cultivation of Sandalwood in India. Present at the Symposium on Sandalwood in the Pacific. USDA Forest Service Gen 122: 66-70.

Vanclay JK. 1994. Modeling Forest Growth and Yield: Application to Mixed Tropical Forest. CAB International, Wallingford, UK.

Wawo AH. 2008. Pelestarian cendana melalui pola lekat lahan di Kabupaten Belu NTT. Jurnal Tehnik Lingkungan 9 (3): 302-313.

Wiharto M, Kusmana C, Prasetyo LB, Partomihardjo T. 2009. Tree diameter class distribution on various vegetation types at Sub Mountain Salak, Bogor, West Java. Jurnal Ilmiah Forum Pascasarjana IPB 31 (1): 13-23.

Wijayanto, N Juliao D. 2011. Pertumbuhan Tanaman Pokok Cendana (Santalum album L.) pada Sistem Agroforestri di Desa Sanirin, Kecamatan Balibo-Timor Leste. Silvikultur Tropika 3 (1): 119-123. [Indonesian]

Zobel BJ, Talbert J. 1984. Applied Forest Tree Improvement. John Willey and Sons, New York 